\title{
TEACHER'” BELIEFS AND PRACTIGES IN ASSESSING THE VIEWING SKILL OF ESL LEARNERS
}

\author{
Mari Karen Lebumfacil Gabinete \\ National University, Philippines \\ mklgabinete@national-u.edu.ph
}

First received: 25 May 2016

Final proof received: 29 May 2017

\begin{abstract}
This study explored the English/Language Arts teachers' beliefs and practices in teaching and assessing students' viewing skills in secondary education in the Philippines. Three secondary teachers in three government-run institutions were surveyed, interviewed and observed regarding their conception of visual literacy. The study revealed that teacher belief is influenced by their early education. In addition, teachers' ability to teach and assess viewing skills relies not only on teacher training but also on access to technology and availability instrutional materials. The study suggests a call to strengthen school or government support in order to promote viewing comprehension in basic education to meet the demands of the 21 st century.
\end{abstract}

Keywords: viewing skill; visual literacy; teacher cognition; pedagogical practices

The Philippines, along with other countries in the world (e.g. United Kingdom [Department for Children schools and families, 2009]; Canada [Ministry of Education Ontario,2006]; Singapore [MOE Singapore,2010]; and Australia [ National Curriculum Board Australia, 2008] undergoes continual curricular revision to address developing forms of literacies. The $\mathrm{K}$ to 12 Education Curriculum of the Philippines is anchored ideally on the notion that students in the "knowledge age" must be "prepared to compete in a global economy, understand and operate complex communication and information systems, and apply higher level thinking skills to make decisions and solve problems" (2013, $\mathrm{K}$ to 12 Curriculum Guide-English).

With the recent integration of viewing in the language macro skills simultaneous with the implementation of K to 12 in school year 2013-2014 and the proliferation of multimedia technology, the challenge to guide our students to select, validate and interpret these visual images are the many arduous tasks teachers have to face and succesfully accomplish.

Face with this situation, educators should take it upon themselves to facilitate the development of viewing skills or visual literacy of our young learners. A dearth in literature that explores Filipino Language Arts teachers' ability to teach and assess this fifth macroskill is noticeable, therefore, this study will attempt to fill that gap. This paper presents the current situation in the Language Arts classroom of basic education by exploring the beliefs and instructional practices of three Language Arts teachers in teaching and assessment of students' viewing skills. The study sought to answer the questions: 1) What are the beliefs of Language Arts teachers regarding visual literacy? 2) How are these beliefs carried out in Language Arts classroom? 3) How do Language Arts teachers assess students' viewing skills?

The following discussion of key concepts and related studies pertaining to visual literacy, teacher beliefs and practices, teaching and assessment of viewing will shed light to the purpose of this research study.

\section{Visual literacy}

Literacy once meant an ability to read and write. Now, it is not sufficient just to be able to read and write. Literacy is a fluid concept, determined by cultural context (Williams, 2004). Its theoretical conception has been evolving owing to the demands of society, such as, more sophisticated ability to assess and interpret traditional print texts and visuals. The change in focus of the traditional reading and writing in language arts classroom demands efforts from teachers to develop various instructional approaches but the reality faced by teachers confront them as they plan their daily Language Arts lesson. For example, according to Considine (1999), teachers who teach subjects that involve film viewing show the entire film. This results to an eventual neglect in analysis and evaluation of the text.

Moreover, Begoray's study (2001) revealed a number of challenges that impede effective implementation of visual literacy. These are: (1) coping with student attitudes, (2) lack of time and (3) their own attitude about the complexities of integrating an expanded notion of literacy. Further, the study revealed that viewing activities in classrooms mostly involve featured analysis (looking at details). Although specified in Language Arts curriculum, appreciation (recognizing quality and/or significance) and criticism (evaluation) are rarely practiced. 
Kalantzis, Cope, \& Harvey (2003) maintained that new learning requires redefining competence, ability, capacity, and intelligence. Assessment techniques such as project assessment of in-depth learning tasks, performance assessment of completion of those tasks, quantification of the ability to work collaboratively in groups, and ongoing documentation of learning experiences through forms of portfolios should all be found in new learning environments. The challenge is for teachers to bridge the gap between new ideas and practical implementation.

\section{The Concept of Teacher' Beliefs}

The term "belief", though one of the most difficult construct to define (Mansour, 2009) is synonymous with Borg's (2003) "teacher cognition" which refers to "the unobservable cognitive dimension of teaching - what teachers know, believe, and think (p.81)." Pajares (1992) maintained that beliefs are reflected only through one's actions and words; hence, are unseen attributes, if one is not observant or inquisitive. Rightly so, Richardson (1996) stated that "relationship between beliefs and practices is interactive" (p.104) because beliefs are perceived to make one act accordingly, which suggests that these beliefs may change as one goes through varying life experiences and reflects on his or her actions. Despite the various definitions which describe beliefs, Kuzborska (2011) holds the notion that teachers possess beliefs regarding their work, their students, their subject matter, and their roles and responsibilities. Further, these teachers' beliefs
(Borg, 2003, 2007) are clustered into more specific categories (e.g. educational beliefs about the nature of knowledge, confidence to perform certain tasks, etc.) from a broader system of beliefs. Following Borg's line of thinking, this study focused specifically on teachers' beliefs about the nature of visual literacy, ability to carry out and assess viewing tasks and challenges that need to be overcome.

Teachers go through their day-to-day regimen equipped with a variety of decisions in order to deliver their daily instructions (Judson, 2006). A plethora of evidence has been presented by research that these decisions are influenced by their beliefs (Borg \& Phipps, 2007; Farrel \& Kun, 2008; Deemer, 2004; Kuzborska, 2011). Teachers' decision about how to conduct visual literacy instruction is not exempt from these, but in order to deliver this fifth macroskill, Language Arts teachers must have a clear concept of what this literacy is all about.

Freeman and Johnson (1998) maintained that a great many part of teachers' knowledge about teaching comes from their experiences as students. However, instead of simply preserving and replicating educational practice, they encourage teachers to acknowledge prior knowledge to be used as tool to strengthen and improve student learning.

The researcher was informed by the diagrammatical representation of teachers' beliefs illustrating the various factors that influence teachers' classroom practices designed by Borg (2003).

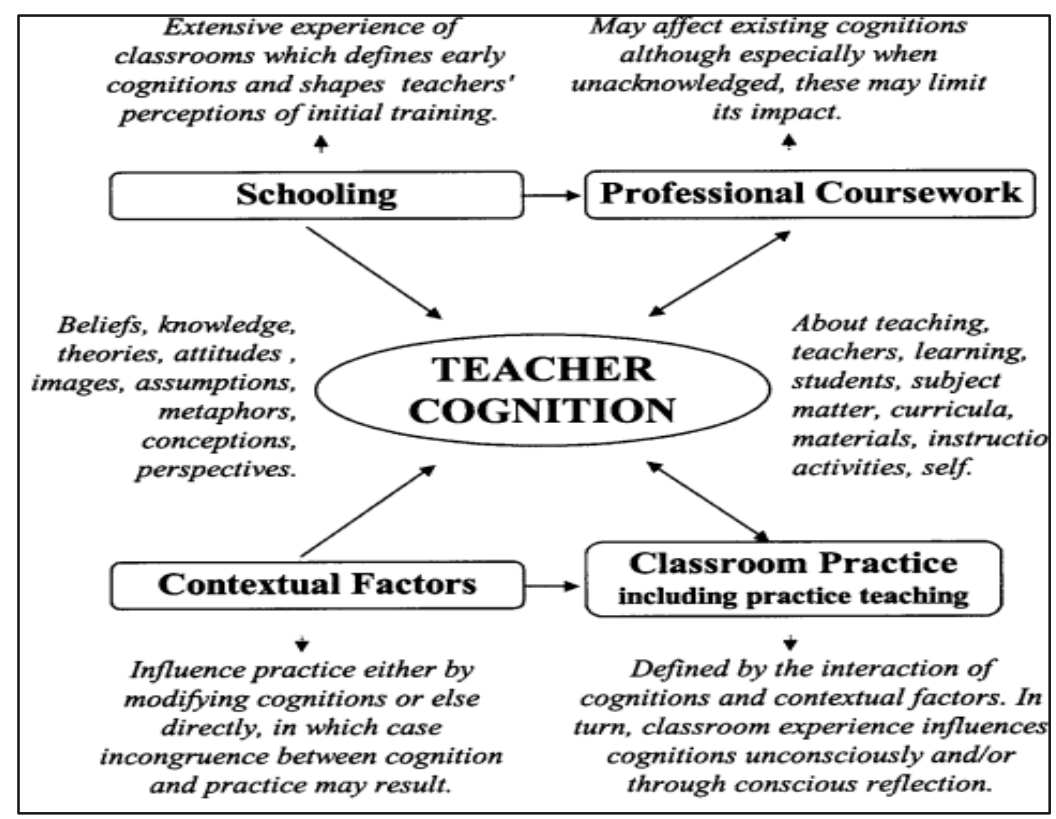

Figure 1. Teacher cognition, schooling, professional education, and classroom practice (Borg, 1997)

\section{Beliefs and Practices in Grammar Teaching}

In order to validate what previous studies account, Phipps \& Borg (2009) examined tensions in the grammar teaching beliefs and practices of three practicing teachers of English in Turkey.The analysis indicated that while in some aspects teachers' practices in teaching grammar were in conflict with specific beliefs about language 
learning, at other aspects, these same practices were consistent with a more generic set of beliefs about learning. It was the core beliefs that were most influential in shaping teachers' instructional decisions.

Farrell and Lim (2005) investigated and compared the grammar teaching beliefs and actual classroom practices of two experienced ESL teachers in a primary school in Singapore. The study revealed a divergent result which they attributed to time factors and teachers' adherence to traditional grammar teaching.

The teaching beliefs and practices of experienced ESL teachers were explored by Barrot (2016) in his study focusing on sociocognitivetransformative approach. The results revealed that beliefs are not always reflected in their classroom practices.

\section{Beliefs and Practices in the Use of Technology}

In the context of literacy instruction, the study of McIntyre (2011) revealed that literacy instruction can be delivered more effectively with the aid of technology. The study concluded that the relationship between teachers' beliefs and practices and their use of technology in literacy instruction is influenced by their pedagogical beliefs, perceived administrative support, the amount and type of professional development received, the ease of access to technology, perceived barriers to technology integration, and teachers' attitudes toward technology integration.

Because technology has redefined visual literacy, teacher Brenda Dyck (2016) believes that educators should seek resources from hollywood movies. Dyck pointed out the message of Martin Scorsese, director and filmmaker, saying essentially, that movies are instrumental in shaping young learners' minds in a critical way. However, teachers need to have knowledge of how to express ideas and emotions visually.

\section{Classroom Practices in Teaching/Assessment of Visual Literacy}

In countries like South Africa and Australia, the teaching and assessment of visual literacy have been of valuable concern owing to the proliferation and increasing consumption of multimodal texts. Teachers of the two countries are challenged by the existing practices and reflect on ways to replace the ineffective ones with more adequate alternatives. Mbelani (2008) challenged his classroom assessment practices and thought of alternative ways to bridge the gap between the National Curriculum Statements (NCS) of South Africa and what was capable of being done as a result of his apartheid learning and teaching experience. He designed a visual literacy lesson unit, with specific reference to advertisements, consisting of seven lessons to be taught over ten school days in Grade 10. The highlight of the lesson should equip learners with elements of visual grammar such as: camera angles and shots, non-verbal communication signs, foreground and background, symbolic meaning of colour, texture, lighting, focus and juxtaposition. In addition to acquainting his students with these meta language of visual design, he also introduced them to manipulative language as presented in logo, motto, brand name, slogan, descriptive language and stereotyping. Lastly, the lesson was designed to encourage analysis and design of advertisements.

In Australia, a call to develop the next level of implementation pertaining to curriculum and assessment aspects exists in different learning institutions. Part of this was the issue of students' ability to interpret and create a variety of texts that combines writing, speech, visual images, electronic and interactive media - referred to as multimodal text (Anstey \& Bull, 2006). One crucial area of the implementation is making available to students the concepts and language to describe and/or discuss what they see and view.

\section{Integrating Visual Literacy in Language Arts Curriculum}

Seglem and Witte (2009) strongly advocate the role of teachers as critical in helping students make meaning out of print and non-print texts and the visual connections that can be created between these two divergent forms. They argue that it is a practical method to bridge the concrete and abstract thinking of students who find it a great challenge to make meaning from text. In the same vein, Keene and Zimmermann (1997) put forward the notion of visualization. To them visualization, the ability to build mental pictures or images while reading, when coupled with reader's prior background knowledge and engagement in the text, significantly affects the reader's understanding of the text.

Instructional materials used in multi-level Language Arts classroom consist mostly of images in various forms, e.g., flashcards, posters and other digital images made available through technology. These materials help to motivate even the most disinterested and passive learner (Keddie, 2009) and "reactivate target language" (Wright, 1989). It seems a waste that most coursebooks are filled with decorative images. Hill (2013) analyzed three ELT coursebooks and found that images serve merely as decoration, if not, are used for "low-level language practice" (Hill, 2013 as cited in Kierandonaghy, 2016, p.1).

The foregoing discussion highlights the review of literature related to teachers' beliefs and practices related to grammar teaching, communicative language teaching, use of technology, and the integration of visuals and visual literacy in Language Arts curriculum. Further, it underscored the many studies performed focusing on the tension between teacher beliefs and practices. 
Noticeably, there exists a dearth of studies that involve beliefs and practices in the area of teaching and assessing visual literacy. Premised on the fact that public school teachers are mandated to teach and assess students' viewing skills, the question begs how exactly is this undertaking to be carried out by teachers in Language Arts classroom and if indeed these classroom practices are effectively implemented with respect to the teaching and assessing of student's viewing skills. This study addresses existing gaps in the literature through investigation of viewing skills as taught and assessed in the context of existing classroom instruction. It represents a qualitative case study approach toward examining visual literacy in actual classroom practice.

\section{METHOD}

\section{Research Design}

This study primarily used description-case study approach to understand the relationship between beliefs and actual classroom practices for teaching and assessing students' viewing skills.

Yin (2003) defines a case study as "an empirical inquiry that investigates a contemporary phenomenon within its real-life context especially when the boundaries between phenomenon and context are not clearly evident" (p.13). Such a design appropriately suits the topic of this study and the type of data collection techniques used to gather the necessary information. The researcher has carefully studied the state of affairs (Fraenkel \& Wallen, 2000) of the three language arts teachers with respect to how visual literacy is conceived, delivered and assessed through self-reported questionnaire, in-depth interview, and classroom observation.

\section{Teacher-Participants}

The participants of the study are three Language Arts teachers who have more than five years of teaching Language Arts in multi-levels. At the time of the study, they are all Language Arts teachers from three Science High Schools in the Philippines.

\section{Data collection techniques/instrument}

A self-reported questionnaire validated by in-depth interview and classroom observation were utilized to explore the participants' conception of viewing skills with respect to teaching and assessment.

\section{Self-Reported Questionnaire}

The questionnaire was a product of the researcher's review of literature on teaching and assessing visual literacy. It was adapted and patterned on the format and item sequencing used by Graham, Santos, and Francis-Brophy (2014) in their study on teacher belief about listening in a foreign language.

\section{Interview}

The following pieces of information were elicited from the participants during the interview which took an average of 30 minutes for each teacher: Questions that explore teacher beliefs regarding teaching/assessing viewing, teaching experience, conception of viewing skill/visual literacy, importance of the skill to students, how they were taught the skill in school, their considerations when preparing lessons that require viewing, and the related trainings they have attended or participated. Similarly, in order to explore teachers' instructional practices, the researcher asked the participants to describe a typical viewing lesson in their language arts class and asked them to explain their specific strategy for pre, during and post viewing of texts.

\section{Classroom observation}

The observation focused on the teachers' practices in teaching and assessment of students' viewing skills and was conducted a week after the administration of self-survey. The researcher paid attention to four areas namely: (1) content, (2) delivery of instruction, (3) methods/teaching strategies and (4) Assessment of students' learning. The researcher conducted a non-obtrusive- wholesession obervation of the Language Art classes of the teacher-participants.

\section{Data Analysis}

Since the study is exploratory in nature, "coding is the pivotal link between data and developing an emergent theory to explain these data" (Charmaz, 2006) because it is through coding that researcher defines what is happening in the data and determines what it means. The data was coded following the research questions posed: beliefs about visual literacy, how this literacy is delivered in the classroom, how this literacy is assessed. During initial coding, relevant codes (i.e., words or group of words) were identified from initial interview and observation. These codes were labelled and categorized into subcategories based on their related properties and dimension. After initial coding, concurrent and progressive data collection was done. This phase was useful in further shaping the subcategories. As part of progressive data collection, theoretical sampling was done to saturate categories being developed and to obtain additional information about the categories (Strauss \& Corbin, 1998). Then, intermediate coding was performed. At this stage, the subcategories were conceptually linked to create fully developed individual categories. Then, these individual categories were linked to one another to create a preliminary theory. Finally, as part of theoretical integration, codes from other established theories were integrated to add explanatory power to the emergent theory-the final product. 


\section{FINDINGS AND DISCUSSION}

As noted, the beliefs and practices of three experienced teachers in selected Science High Schools in Metro Manila are the focus of this research. Further, it aimed to determine whether these beliefs are reflected in their instructional practices.

Based on teacher responses from self-reported questionnaire and interview, the data revealed general insights into teachers' conception about the scope and nature of viewing skills.

\section{Research Question \#1}

What are the beliefs of Language Arts teachers regarding visual literacy?

The three teacher-participants gave a blurred conception of what visual literacy is. For example, T1 mentioned the concept of visual-spatial but gave a general view of what visual literacy is about.

T: Ahm... multiple intelligences will go to that (sic) and that is the visual-spatial. I think it's more on viewing and letting the students analyze what they had viewed.

When probed deeper about their understanding of visual literacy, one teacher openly admitted that she has no idea nor even heard of the word, although, she made a strong point when she said that visualizing is reading using imagination.

T3: No, I never heard... and we know that when we say visual literacy, it has to do with visuals...

T2: What do u mean by that? There's a picture? Like for example, a certain advert, picture? in real life, they use these things, like when they go to the airport, the kind of viewing is more functional...

Aside from a fuzzy description of visual literacy, the self-report reveals that teacherparticipants regard visual literacy as less challenging compared to reading. Reading, according to the participants are given more emphasis in Language Arts. Also, they recognize the responsibility of having students realize that an image has an ability to project multiple meaning to the viewer. Moreover, when asked about their view on the main purpose of carrying out viewing tasks, they all gave the highest mark on developing the students' ability to understand and communicate with images.

Despite the foregoing, teacher-participants are not strongly convinced of:

- $\quad$ their awareness of what aspect and features of multimodal text to teach and assess, and

- $\quad$ their attitude of viewing text as worthy of critique is likely to be adopted by their students

Findings from interview and self-report suggest that teacher-participants may not have been explicitly trained how to conduct the concept of visual literacy to young learners. Borg (2003) underlined the various factors of how teachers' cognition is developed. Teachers' early education plays a significant role in shaping certain beliefs. In addition, teacher-participants may not have been provided the necessary training during teacher education in addition to the inability of the institution with which they belong to value the skill through in-service seminars and workshops. This negligence translates to teachers'giving less premium to visual literacy.

\section{Research Question \#2 \\ How are these beliefs carried out in Language Arts classroom?}

In the interview, teacher-participants were asked about the most important procedure they follow and why they do them. The responses seem to reflect a professionally engaged teacher:

- warm-up activity to set the mood or activate schema,

- $\quad$ post guide questions,

- $\quad$ viewing of the material, and

- discussion and synthesis to make the viewing meaningful.

In order to understand the teachers' typical viewing day, this researcher probed into teachers' practices. In response, these accounts were reported:

T1: I go about the usual routine, word of the day, idiom of the day, then proceed to lesson. Today, my students will present their creative output in response to the advocacy video they viewed given as homework.

T2: ...they love viewing, they love using their eyes, they enjoy watching and listening and get so excited every time I would ask them to see a video clip. I pose questions to be answered at end of viewing.

T3: Actually, if its all about the story, I ask them first a question about the moral of the story. If for example I will ask them a question on values. unlock first, if they can't understand the words they can't understand the story, I let them view the animated movie, then I give comprehension questions, at least 5 questions, reading is also viewing with imagination.

Interestingly, teacher-participants reported a thrice-weekly use of visuals, specifically moving images. When viewing films, for example, students are provided a pre-viewing activity such as: asking students prior knowledge of the material, what students want to learn from the material, and let students predict what the material was all about. However, during viewing, the teacher-participants have divergent methods in processing the material. While two (T2 \& T3) were convinced that materials such as film, should be viewed in its entirety before any discussion happens, one (T1) teacher-participant would instead, interrupt the viewing to ask students' answers to some guide questions posed in the beginning of the viewing activity. In wrapping-up a viewing activity, teacher-participants all agree that they always ask students what the most interesting idea or visual element was, what made the material 
effective and how they would describe and rate the material based on a standard criterion. Advocates of visual literacy maintain the value of using films to develop learners' critical thinking (Scorsese in Dyck, 2016) and implicitly reactivate target language (Keddie, 2009).

T1: I'm not sure, other teachers are also doing the same...it is a common thing for teachers to use films...Actually, I only ask them to watch a film then they will do a film critique.

While films are common instructional materials used in Language Arts classroom to explore history, popular novels and short stories in literature, Dyck (2016) noticed that the language of film was never mentioned. This "grammar" involves, for example, camera angles, lighting, and other visual elements. Clearly, teachers have an incomplete, unclear understanding of the concept of viewing skill or visual literacy. Because of teachers' inability to clearly get a grasp of the notion of viewing skills due to their lack of training in teaching and assessment of visual literacy, instructional materials are mostly films or video clips that they themselves download from the Internet but based on self-report, films or video footages are used only for motivation to engage students in the reading of literary text.

Another teacher's view of the concept of visual literacy is the use of visual aids such as advertisements, pictures, posters. She stated the importance of visual literacy in enabling the students to recall or memorize a certain product as presented in advertisements.

T2: ... using of visual aids, like ads, then posters, anything to do that the eyes can see I think you have to...in visual literacy...you try to remember, visualizing, memorize, recall.

As reported, teacher-participants "rarely" use viewing activities from textbooks because of many reasons: First, it is time consuming, second, the level of difficulty is not suitable for all students, and lastly, it promotes laziness for teachers. On the positive side, textbook viewing activities are readily available to students/teachers anytime, reinforce lesson, and illustrate through image the idea presented in printed text. However, it cannot be helped that teachers sometimes rely on materials available in government-prescribed textbooks. Although, the study of Hill (2013) revealed a sorry state about how images are used in Language Arts coursebooks - merely for decorative purposes only.

T3: most of the time when I don't have prepared materials I refer to modules, modules come with picture and questions, prepared by DepEd (Department of Education).

Teacher-participants reportedly use various strategies in conducting visual literacy lessons. These are: think-aloud, visual thinking and discussion of metaphors and symbols. These strategies understandably produce different creative outputs.

A cursory look at teachers' responses seem to reflect an ideal Language Arts class where activities follow certain instruction design based on an equally ideal curriculum. However, as noted by Phipps and Borg (2009), beliefs are influenced by the ways they are elicited. This means that responses from questionnaires "may reflect teachers' theoretical or idealistic beliefs" (p.382). On the contrary, when beliefs are elicited through discussion of what happens in the classroom, then, these beliefs are more grounded on reality, thus, reflect teachers' "practical or experiential knowledge" (p.382).

\section{Research Question \#3 \\ How do Language Arts teachers assess students' viewing skills?}

Generally, teachers rely on student reflection to assess students' viewing skills.

T3: I ask them to write their reflection, journal is different, in our module there is a ready-made rubric...

T1: Actually, I only ask them to watch a film then they will do a film critique.

In assessing students' viewing skills, T2 is proud to report that her students are stimulated by her viewing activities where a background of the story is discussed after which a battery of questions ensues.

T2. Why you are going to be this? What is the main reason why we have to view the film? I have to ask them their opinion not in the box, follow up questions.

A common practice among teachers in the study, is the showing of film or video clip usually in literature classes. Although teachers asked about the film's message, other dimensions of critical analysis of viewed material was given less importance if not completely neglected. The teacher could have seen this as an opportunity to enhance students' verbal or writing skills or their chance to develop, enhance their critical and creative thinking skills. Begoray (2001) revealed these lapses in his study about viewing and representing approaches of three Canadian Language Arts teachers. He noted that viewing activities mostly involve looking at details but rarely is appreciation and criticism practiced.

In the case of $\mathrm{T} 3$, animated version of the movie was selectively shown to meet the demands of a younger group of students (Grade 7). In her Literature class, T2 uses video clips of poetry presentation to be used as model for students to emulate while T1 posed questions before allowing students to view an advocacy video which was given as assignment prior to classroom observation. Due to time constraint, the viewing of an entire film is rarely done in one session. For the latter, a creative presentation is the expected output from 
students. For T1's class, the topic of "stereotyping in advertisements" generated various enactment of interpretations (e.g. rap \& dance number, role-play, pretend interview) performed in groups. The students were actively involved in the lesson, in fact, Kalantzis, et.al (2003) mentioned that ability to work collaboratively in groups makes for a good assessment technique if new learning requires a redefined competence, ability, capacity, and intelligence. However, Brumberger suggests that "written and oral language must be complemented by proficiency with visual language" (2005, p. 320).

Although film viewing may be a common practice among teachers, it is imperative that learners are equipped with the ability to critically assess these images and make meaning from them (Curriculum Planning \& Development Division, 2010). If students are not given the opportunity to learn and express themselves in terms of images, then the definition of visual literacy is indeed a vague notion even to experienced teachers (Braden, 1998).

In one of the Language Arts classes that this researcher has observed, T1 acted merely as facilitator letting the students present a project that asked them to view an advocacy campaign. The students responded to the ad campaign through various representing techniques such as creating advertisement song, composing a song and rap, writing and acting a skit. Here, the teacher had delivered a lesson that illustrates the viewing skill of students despite his lack of experience. A common practice among all teachers observed.

Based on the researcher's observation and interview with teachers, elements of an image (or single shot from a film) are never discussed. Students are not oriented on camera angles, nonverbal communications signs, symbolic meaning of colour, etc. For example, in T1's class, the analysis of advertisement focused only on the message of stereotyping. Hence, students concentrated their creative output on their negative attitude towards stereotyping and how they should fight stereotyping by illustrating in various creative ways. This could be the result of T1's lack of training on how to conduct a viewing class. However, this is a typical scenario in all observed Language Arts classes.

This observation contradicts with the study of Richardson (1996) that beliefs may change as one goes through varying life experiences and reflect on his or her actions. The study of Barnett (2011) revealed that even among exemplary teachers who possess high level of beliefs, the sense of reflection is exhibited in their classroom activities. A redeeming point in $\mathrm{T} 1$ 's class, however, was the students' active and engaging activities in response to the viewed material upon the innovative and creative instruction of the teacher.

In another classroom (T2), students were made to view a spoken poetry while teacher instructs students to mimic the delivery technique of the presenters. Here, the viewing part was only incidental because the spoken poem was also presented in written form and projected on screen.

A case study conducted by McIntyre (2011) revealed that the role of technology is significant in literacy instruction because it enabled teachers to manage classroom behaviour effectively and use them to deliver classroom instruction efficiently.

Technology has become equated with viewing especially in literature classes where film viewing has been the best instructional material. It is interesting to note, that when observed, teacherparticipants use visual materials as instructional tool to motivate students for the lesson proper, however, a significant amount of time was wasted due to teachers' inability to properly set visuals with the aid of technology. Thus, a technology-savvy student would be tapped to assist the helpless teacher.

The limited provision of resources is a fairly common challenge faced by teachers in government-run institutions. In a developing country like the Philippines, teachers rely on selflearned skills of their students rather than students receiving this new form of literacy from their teachers. Borg (2003) believed that contextual factor such as the circumstances that the teacher is engaged in thwarts the teachers' ability to promote visual literacy among students. In the research site (a government-run institution) and in the Philippines in general, access to technology is mostly enjoyed by private schools. Teachers in the government, bring their own equipment such as overhead projector, laptop, in addition to electric fan, if their lesson requires the use technology as in the case of film viewing.

What was evident in the observed language arts classroom was the teachers' lack of knowledge in the language of visuals. In review of literature related to teaching and assessing visual literacy Mbelani, (2008) and Anstey \& Bull (2006) provided their young students the concepts and language to describe and/or discuss what they see and view adapted from the framework designed by Kress and van Leeuwen (1996) on reading visual images. Although self-report revealed an ideal classroom viewing scenario, the researcher failed to observe these self-reported practices in class. This phenomenon as noted by Pajares (1992) states that beliefs are reflected through one's action and words. However, this investigation has shown that one's action is not always congruent to one's words.

Teachers' common belief about viewing is rooted on their previous learning and teaching experiences. $\mathrm{T} 1$, whose experience as a student in a provincial high school, lacks the knowledge and skills to teach nor assess viewing skills of students. However, having committed to 'transform' his method of teaching and adapting to the concept of 21 st century learning, his language arts classroom 
reflects students' ability to respond creatively using various representing techniques in response to a viewed propaganda image with accompanying text.

\section{CONCLUSION}

This study aimed to determine the beliefs and pedagogical practices of three experienced language teachers in relation to viewing skills. Based on the findings, the three teacher-participants who teach Language Arts to Junior High School in the Philippines believe that visual literacy involves the use of visuals such as pictures, posters, films, advertisements. Apparently, they have no formal concept of this "new" skill except to use images in their Language Arts classes. Seemingly, the reason for this belief has to do with how they were schooled in their basic education and in their undergraduate teacher education. Language Arts teachers who were educated in a public school system in the Philippines, whose instructional resources and school facilities have been desperately in need of support and assistance from local and national government, are predisposed to developing a set of pedagogical beliefs and practices not different from the kind of classroom instructions they have received from their primary and secondary teachers. Not one of the teacherparticipants made any direct mention of analyzing the visual elements such as camera angle, interaction of participants in the image towards one another or towards the viewer, the symbolism of colour or the placement of the image against the space or frame, just to name a few. The summer inservice trainings they receive yearly do not give much importance to the skill. In fact, it is never mentioned.

The term "visual literacy" may be unknown to the three teacher-participants but the old pedagogical practices of teaching and assessing this $21^{\text {st }}$ literacy is still being practiced. For example, as students were instructed to view a particular nonlinear image (e.g. film, video), the only standard question raised refers to the message of the text. Understandably, students respond accordingly focusing on what the text means to him/her. But teaching visual literacy is not exclusive to personal meaning of the text in relation to the viewer. Teachers have the responsibility to teach the language of visuals, only if they are informed of the nature and scope of visual literacy, aside from teaching students how to make meaning of multimodal texts.

As to be expected from experienced teachers, teacher-participants claimed various pre-, during, and post-viewing strategies, however, these activities were not utilized in the viewing lesson observed. The use of technology plays a significant role in the delivery of viewing lesson, however, the limited quantity of equipment for teacher/student use is a constant challenge. Understandably so, teacher-participants schedule their viewing lessons accordingly or, are compelled to personally provide their needs when viewing lesson necessitates the use of overhead projector, laptop or video player. The incrongruent relationship between stated beliefs and actual practices of three teacher-participants on teaching viewing skills was demonstrated in the study by cross-validation of data based on selfsurvey, interview, and observation.

Based on findings, the three teacherparticipants agree that viewing comprehension can be measured by responding to the basic question of what the image is all about, in the case of film-a film critique in response to guide questions. Although visual literacy experts maintain that an image projects multiple meaning to the viewer, the teachers were observed to miss the opportunity to go beyond the basic question of personal meaning. Allowing students to illustrate their understanding of a visual text through various creative modes addresses more the multiple intelligences of learners-a most welcome strategy in inclusive education. Here, the teacher focused on students' delivery of output rather than the actual analysis of the visual material. Clearly, the three teacherparticipants demonstrated a mismatch of stated beliefs and practices in assessing the viewing skills of students, perhaps, due primarily to lack of training and exposure to the formal nature and pedagogical practices involved in visual literacy.

Generally, the findings of this study suggest that, due to factors that have to do with previous schooling, teaching experiences, institutional support and personal initiative, experienced teachers in the Philippines may need to undergo specific training in teaching and assessing viewing skills and other emerging forms of literacy. In addition, the findings reveal an urgent concern for the government to address the lack of support provided to public school teachers. The plight of teachers in the three public schools may reflect the condition of other public schools in other parts of the country. Issues like limited number of equipment and inadequate holdings of updated instructional and resource materials are serious concerns teachers have to contend with in order to address the needs of $21^{\text {st }}$ century learners. All these suggest that, apparently, the Philippine Department of Education is ill-prepared for the education of 21 st century learners who are racing against their teachers in collecting, storing, manipulating information from the world wide web through creative and innovative use of technology. Teachers in the three public schools seem inadequately informed, hence; in dire need of training to teach the $5^{\text {th }}$ macro skill. Nevertheless, there are dedicated and passionate teachers who try their best to make their language arts classroom conducive to learning by enabling 
their students to create, design, produce outputs that test their critical thinking skill.

\section{Directions for future research}

Scholars who are interested in pursuing a similar study may find it useful to evaluate the curriculum of teacher education program and consequently propose an alternative curriculum that targets the needs of future Language Arts teachers who are expected to be knowledgeable about the demands of $21^{\text {st }}$ century learners. The product of this research may bring new development and open opportunities for curriculum developers in the Philippines who ought to be abreast of the newly augmented skills, viewing and representing, which have been in use by learners in the $\mathrm{K}$ to 12 curriculum of other countries.

\section{REFERENCES}

Anstey, M., \& Bull, G. (2000). Reading the visual: Written and illustrated children's literature. Sydney, NSW, Australia: Harcourt.

Barrot, J. (2016) Examining the Teaching Beliefs and Practices of Experienced ESL Teachers: A Sociocognitive-Transformative Perspective. 3L: Language, Linguistics, Literature, 22(1),

Begoray, D. L. (2000). Seventy plus ideas for viewing and representing (and they're not just for language arts!). English Quarterly, 32(1\&2), 30-40.

Borg, S. (2003) Teacher cognition in language teaching: A review of research on what language teachers think, know, believe, and do. Language Teaching, 36(2), 81-109.

Borg. S. \& Phipps, S. (2007). Exploring relationship between teachers' beliefs and their classroom practice. The Teacher Trainer, 21(3), 17-19.

Brumberger E. R. (2005). Visual rhetoric in the curriculum: Pedagogy for a multimodal workplace. Business Communication Quarterly, 68, 318-333.

Charmaz, K. (2006). Constructing grounded theory. London: SAGE Publications.

Considine, D. (1999). Visual images: Integrating imagery into instruction. Englewood, Colorado: Libraries Unlimited.

Curriculum Planning \& Development Division (2010). English language syllabus: Primary \& secondary (express/normal [academic]). Ministry of Education, Singapore.

Deemer, S.A. (2004). Classroom goal orientation in high school classrooms: Revealing links between teacher beliefs and classroom environments. Educational Research, 46(1), 73-90.

Donaghy, Kieran (2016). Visual literacy in the language curriculum. Retrieved from https://visualartscircle.com/2016/12/04/visualliteracy-in-the-language-curriculum/

Dyck, B. (2017). Teaching visual literacy. Retrieved from

http://www.educationworld.com/a_tech/colum nists/dyck/dyck035.shtml

Farrell, T. S. C., \& Kun, S. T. K. (2008). Language policy, language teachers' beliefs, and classroom practices. Applied Linguistics, 29(3), 381-403.

Farrell, T. S. C \& Lim, P. C. P. (2005). Conceptions of grammar teaching: A case study of teachers' beliefs and classroom practices. TESL-EJ, 9(2), 1-13.

Fraenkel, J. R., \& Wallen, N. E. (2000). How to design and evaluate research in education. New York, NY: McGrawhill Companies, Inc.

Freeman, D., \& Johnson, K. (1998). Reconceptualizing the knowledge-base of language teacher education. TESOL Quarterly, 32(3), 397-417. [i]

Graham, Santos, \& Francis-Brophy (2014). Teacher beliefs about listening in a foreign language. Teaching and Teacher Education, 40. 44-60.

Hill, D. (2013). The visual elements in EFL coursebooks, in Developing Materials for Language Teaching, $2^{\text {nd }}$ ed. pp. 158-66. London: Bloomsbury

Jaccard, J., \& Jacoby, J. (2010). Theory construction and model-building skills: A practical guide for social scientists. New York: The Guilford Press.

Judson, E. (2006). How teachers integrate technology and their beliefs about learning: Is there a connection? Journal of Technology and Teacher Education, 14(3), 581-597.

Kalantzis, M., Cope, B., \& Harvey, A. (2003). Assessing multiliteracies and the new basics. Assessment in Education, 10(1), 15-26

$\mathrm{K}$ to 12 English Curriculum Guide (2013) Retrieved from http://www.deped.gov.ph/sites/default/files/En glish\%20CG\%20Grade\%20110\%2001.30.2014.pdf

Keddie, J. (2009). Images. Oxford: Oxford University Press.

Keene, E.O., \& Zimmermann, S. (1997). Mosaic of thought: Teaching comprehension in a reader's workshop. Portsmouth, $\mathrm{NH}$ : Heinemann.

Kress, \& van Leeuwen (1996). Reading visual images: The grammar of visual design. Psychology Press.

Kuzborska, I. (2011). Links between teachers' beliefs and practices and research on reading. Reading in a Foreign Language, 23(1), 102128

Mbelani, M. (2008). Winds of change in teachers' classroom assessment practice: A self-critical 
reflection on the teaching and learning of visual literacy in a rural eastern Cape High School. English Teaching: Practice and Critique, 7(3), pp.100-114.

Mansour, N. (2009). Science Teachers' Beliefs and Practices: Issues, Implications and Research Agenda. International Journal of Environmental \& Science Education, 4(1), 2548

McIntyre, B.K. (2011). Teachers' beliefs and practices regarding the role of technology in literacy instruction: A mixed methods study. UMI Dissertation Publishing by ProQuest LLC.

Ministry of Education Ontario. (2006). The Ontario curriculum grade 1-8 (Language). Ontario, CA: Ministry of Education.

MOE Singapore. (2010). English language syllabus 2010 (Primary \& Secondary). Retrieved from http://www.moe.gov.sg/education/syllabuses/la nguages-and-literature/files/english- primarysecondary-express-normalacademic.pdf

National Curriculum Board Australia. (2008). National English curriculum: Initial advice paper. Retrieved from http://www.acara.edu.au/k6.boardofstudies.ns w.edu.au/english/english_index.html

Pajares, M. F. (1992). Teachers' beliefs and educational research: Cleaning up a messy construct. Review of Educational Research, 62(3), 307-332.

Phipps, S., \& Borg, S. (2009). Exploring tensions between teachers' grammar teaching beliefs and practices. System, 37(3), 380-390.

Richardson, V. (1996). The role of attitude and beliefs in learning to teach. In Sikula (Ed.). Handbook of research on teacher education. New York, NY: Macmillan.

Seglem, R., Witte, S. (2009). You gotta see it to believe it: Teaching visual literacy in the English classroom. Journal of Adolescent \& Adult Literacy, 53(3), 216-226

Strauss, A., \& Corbin, J. (1998). Basics of qualitative research: Techniques and procedures for developing grounded theory (2nd ed.). Thousand Oaks, CA: SAGE.

Williams, B.T. (2004). "A puzzle to the rest of us": Who is a "reader" anyway? Journal of Adolescent \& Adult Literacy, 47(8). Retrieved October 18, 2008, from www.readingonline.org/ newliteracies/lit_index.asp?HREF=/newliteraci es/jaal/5 -04_column_lit/index.html

Wright, A. (1989). Pictures for language learning. Cambridge: Cambridge University Press.

Yin, R. K. (2003). Case study research: Design and methods, 3rd ed. Applied Social Research Methods Series, vol.5. SAGE: London. 